\title{
ANALISIS DAN PERANCANGAN SISTEM BASIS DATA CATATAN WAKTU KERJA DAN PROYEK KARYAWAN PADA PT REKAYASA ENGINEERING
}

\author{
Rhio Sutoyo; Franky Hadinata Marpaung \\ Computer Science Department, School of Computer Science, Binus University \\ Jl. K.H. Syahdan No. 9, Palmerah, Jakarta Barat 11480 \\ rsutoyo@binus.edu; fmarpaung@binus.edu
}

\begin{abstract}
The purpose of this research is to analyze and implement a system for recording employee working time and project time, leave request, overtime request, proposal submission, and paperwork revisions registration at PT Rekayasa Engineering. Collecting information is conducted by surveys to the company, interviews with several employees in the company, and examining documents and procedures used by PT Rekayasa Engineering. The database design is created using lifecycle methodology, namely: conceptual design, logical design, and physical design. The result of this research is a database system which is designed and can be used to process operational procedures of the company and to record the working time and project needed by the PT Rekayasa Engineering. Furthermore, this research also produces a prototype application that can be used as a working model for the system. Using the new database system and the application, information needed by the company is fulfilled. Thus, it allows the company to work more effectively and efficiently.
\end{abstract}

Keywords: system analysis, database system, working time recording, application design

\begin{abstract}
ABSTRAK
Tujuan penelitian ini adalah untuk menganalisis dan mengimplementasi sistem pencatatan waktu kerja karyawan dan proyek, pengajuan cuti, pengajuan lembur, pengajuan proposal, dan pencatatan revisi berkas kerja pada PT Rekayasa Engineering. Metode penelitian yang digunakan untuk mencari informasi adalah dengan survei langsung ke perusahaan, wawancara dengan pihak terkait, dan mempelajari dokumen serta prosedur yang digunakan oleh PT Rekayasa Engineering. Perancangan basis data menggunakan metodologi database lifecycle yaitu: perancangan konseptual, logikal dan fisikal. Hasil yang dicapai dari penelitian ini adalah sebuah sistem basis data yang dibentuk dan dapat digunakan untuk memproses prosedur operasional perusahaan serta pencatatan waktu kerja dan proyek yang dibutuhkan oleh PT Rekayasa Engineering. Selain itu, penelitian ini juga menghasilkan prototipe aplikasi yang dapat digunakan sebagai model yang bekerja untuk sistem yang sedang berjalan. Dengan adanya sistem basis data dan aplikasi yang dihasilkan, informasi yang dibutuhkan oleh perusahaan dapat terpenuhi dan memungkinkan perusahaan untuk bekerja secara lebih efektif dan efisien.
\end{abstract}

Kata kunci: sistem analisis, sistem basis data, pencatatan waktu kerja, perancangan aplikasi 


\section{PENDAHULUAN}

Setiap perancangan bangunan membutuhkan waktu yang berbeda-beda karena masing-masing rancangan memiliki tingkat kesulitan yang beragam. Umumnya perusahaan yang bergerak dibidang konsultasi dan perencanaan dalam sebuah proyek pembangunan akan sangat membutuhkan informasi yang bersangkutan dengan proses pembuatan sebuah proyek perancangan, seperti kapan sebuah proyek dikerjakan, kapan proyek selesai dikerjakan, pengiriman laporan, pengiriman proposal, dan sejarah-sejarah berkas prestasi perusahaan terhadap proyek apa saja yang telah tercapai dan gagal dicapai. Data-data tersebut nantinya dapat digunakan untuk evaluasi terhadap perusahaan, kontrol kerja, perhitungan waktu kerja karyawan, dan penggajian karyawan tersebut.

Kurangnya informasi mengenai teknologi komputer mengakibatkan banyak perusahaan yang masih menggunakan sistem manual. Beberapa hal yang sering menjadi kendala ketika menggunakan sistem manual pada perusahaan besar dan sedang berkembang adalah saat melakukan pencarian data. Data adalah informasi mentah terekam yang dapat menyediakan informasi lainnya. Data informasi mentah dapat tidak berarti jika tidak digabungkan dengan data yang lain (Atzeni, 2003, p2). Data yang disimpan secara manual atau tertulis sulit untuk dicari dikarenakan data-data tersebut masih berupa dokumen yang tertulis. Perusahaan yang menggunakan sistem manual juga akan dihadapkan kepada masalah kehilangan dokumen tertulis dan harus merelakan informasi yang berada pada dokumen tersebut. Hal ini membuat data dan informasi yang dimiliki perusahaan tersebut menjadi tidak aman, karena informasi perusahaan dapat ditemukan atau diambil oleh pihak lain yang tidak memiliki hak untuk melihat informasi tersebut. Masalah lain yang sering muncul ketika suatu perusahaan menggunakan sistem manual adalah menurunnya keakuratan data dan informasi yang ada disebabkan oleh lamanya pembuatan dokumen laporan.

PT Rekayasa Engineering ini masih menggunakan sistem manual atau tertulis untuk kegiatan operationalnya, yaitu dalam pencatatan waktu kerja dan proyek, pengajuan cuti karyawan, pengajuan lembur karyawan, pengajuan proposal karyawan, dan pencatatan revisi berkas kerja. Melihat kondisi perusahaan yang seperti ini, dibutuhkan suatu sistem informasi yang dapat membantu PT Rekayasa Engineering dalam mengelola data-data tersebut. Salah satu caranya adalah dengan menghubungkan data-data tersebut ke dalam suatu database. Database adalah kumpulan data yang terorganisir dan secara logika berkaitan. Terorganisir adalah data distrukturkan sehingga mudah untuk disimpan, dimanipulasi, dan diperoleh oleh pengguna (Hoffer, 2009, p46). Untuk memanipulasi database, digunakan bahasa query atau disebut dengan structured query language (SQL) yang dapat ditemukan di berbagai paket manajemen database (O’Brien, 2003, p148).

Tujuan dari penelitian ini adalah untuk menghasilkan sistem pencatatan waktu kerja dan proyek, pengajuan cuti, pengajuan lembur, pengajuan proposal, dan pencatatan revisi berkas kerja yang sudah terkomputerisasi untuk PT Rekayasa Engineering. Diharapkan aplikasi ini dapat menyediakan kemudahan bagi PT Rekayasa Engineering untuk dapat mengakses informasi dan memudahkan dalam pembuatan laporan perusahaan melalui fitur-fitur yang ada di dalam sistem yang akan dibuat.

Ruang lingkup dari aplikasi ini dibatasi pada proses pembentukan dan pengajuan proposal oleh Marketing ke pihak Project Management \& SCPC; proses pembentukan management tim dan berkas kerja yang akan dikerjakan oleh karyawan dengan kontrol catatan waktu pengerjaan setiap berkas dari karyawan ke pimpinannya, SDM, dan Project Management; proses pengerjaan berkas berikut dengan pencatatan revisi kerja berkas; proses pembuatan dan pengajuan cuti oleh karyawan sampai ke pihak SDM; proses pembuatan dan pengajuan lembur oleh karyawan sampai ke pihak pimpinannya. 


\section{METODE}

Metodologi yang kami gunakan dalam penelitian ini antara lain adalah dengan menggunakan metode studi lapangan, studi pustaka, dan database lifecycle (Connoly, 2002, p271).

\section{Database Lifecycle}

Menurut Connolly, sebuah sistem basis data adalah komponen dasar dari sistem informasi organisasi yang lebih besar, daur hidup aplikasi basis data berhubungan erat dengan daur hidup sistem infromasi. Tahapan daur hidup aplikasi basis data adalah sebagai berikut (Gambar 1):

\section{HASIL DAN PEMBAHASAN}

\section{Analisis Sistem yang Berjalan}

Untuk menentukan kebutuhan informasi yang dibutuhkan, diperlukan adanya observasi pada sistem perusahaan yang berjalan sebelumnya. Sistem yang diamati meliputi, prosedur dan proses pengajuan proposal pengerjaan proyek, pengajuan laporan waktu kerja atau timesheet, proses pembentukan tim proyek dan pembagian proyek, pencatatan revisi kerja proyek, pengajuan cuti dan pengajuan ijin lembur.

Berdasarkan hasil observasi dan wawancara yang telah dilakukan pada PT Rekayasa Engineering, diperoleh gambaran proses kerja sebagai berikut:

Prosedur dan proses pengajuan proposal (Gambar 2) adalah: (1) marketing membuat proposal berikut dengan penawaran; (2) proposal diberikan kepada client dan jika proposal tidak diterima, akan kembali ke marketing berikut dengan keterangan kenapa proposal ditolak; (3) proposal diberikan kepada client dan jika proposal diterima maka akan menjadi sebuah proyek; (4) setelah proposal diterima, dibentuk sebuah tim pengembangan untuk proyek.

Proses pembentukan tim proyek dan pembagian proyek (Gambar 3) adalah: (1) setiap proyek terdiri dari engineering proyek, project management, dan supporting (SDM, keuangan, IT, fasilitas); (2) setiap bagian kepala departemen (kadep) pada Departemen Engineering memilih anggotanya untuk menjadi pemimpin dalam proyek (di dalam perusahaan disebut dengan Lead). Kadep bagian Electrical / Instrument memilih 1 Lead untuk Electrical / Instument dalam sebuah proyek tertentu untuk bagian engineering proyeknya. Kadep bagian Mechanical / Piping memilih 1 Lead untuk Mechanical / Piping dalam sebuah proyek tertentu untuk bagian engineering proyeknya. Kadep bagian Proses memilih 1 Lead untuk Proses dalam sebuah proyek tertentu untuk bagian engineering proyeknya. Kadep bagian PDS \& IT memilih 1 Lead untuk PDS \& IT dalam sebuah proyek tertentu untuk bagian engineering proyeknya. Kadep bagian Civil memilih 1 Lead untuk Civil dalam sebuah proyek tertentu untuk bagian engineering proyeknya; (3) setiap Lead memimpin beberapa Engineer, Designer, Drafter dan Staff berdasarkan bagiannya dalam setiap proyek. Dan mereka terdiri dari senior, biasa, dan junior; (4) Setiap Lead menentukan file-file yang mana saja yang akan dikerjakan oleh Engineer, Designer, Drafter, dan Staff yang mereka pimpin. 


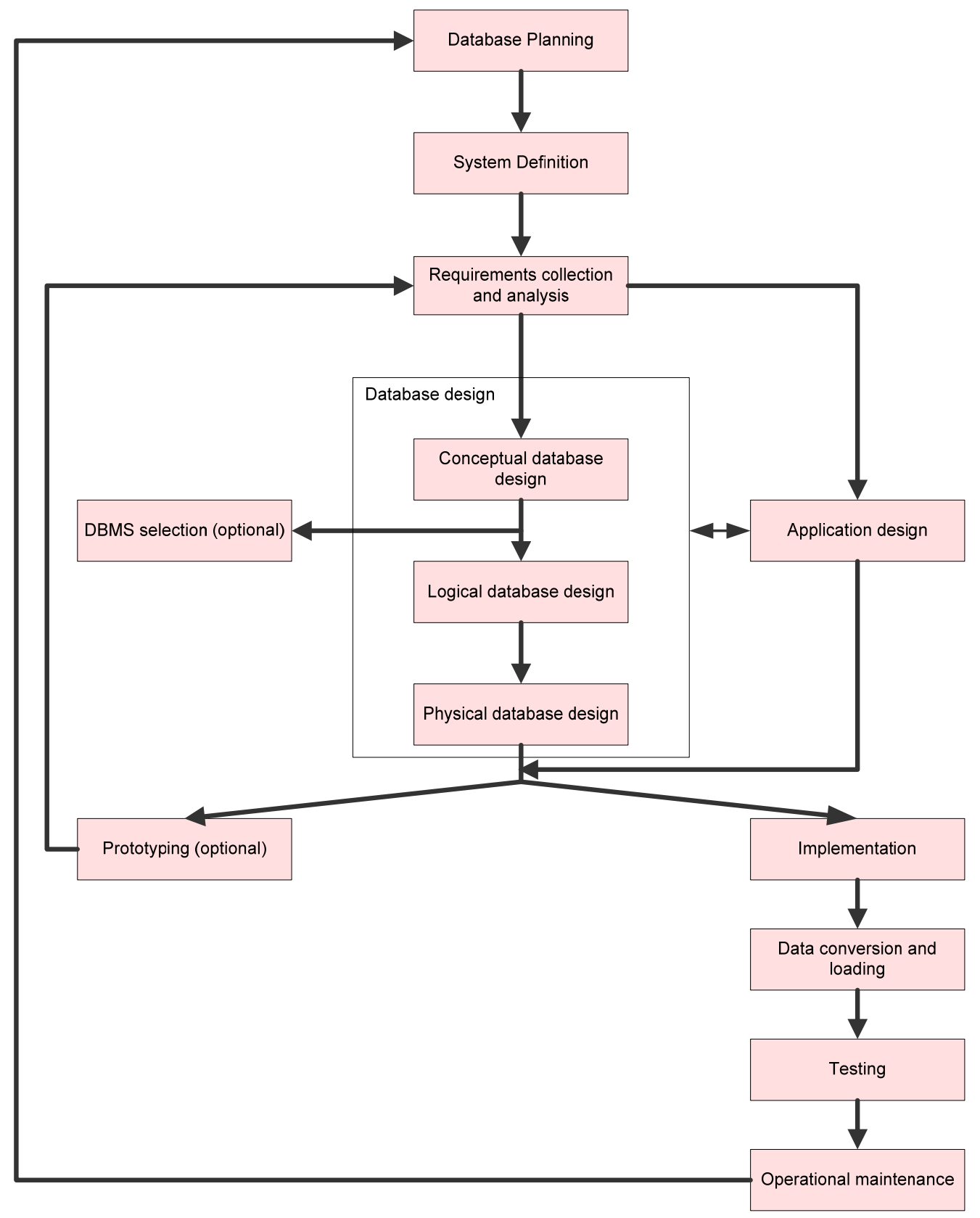

Gambar 1 Daur hidup basis data

Sistem pengisian laporan waktu kerja atau timesheet (Gambar 4) adalah: (1) setiap anggota Engineering proyek diwajibkan untuk mengisi timesheet untuk laporan waktu kerja mereka; (2) laporan diisi pada periode tertentu, yaitu satu minggu sekali; (3) setiap hari waktu kerja PT Rekayasa Engineering adalah delapan jam; (4) anggota Engineering proyek dapat melakukan lembur jika pada hari tertentu, telah dilakukan pekerjaan selama delapan jam dan tidak telat mengenai kehadiran. Waktu tersebut dianggap dengan waktu lembur; (5) setelah melakukan pengisian, berkas timesheet diberikan kepada setiap Lead atau pemimpin dalam Engineering proyek; (6) jika berkas ditolak oleh Lead, anggota Engineering proyek harus mengisi kembali; (7) jika diterima oleh Lead, berkas diberikan kepada bagian SDM; (8) SDM melakukan manajemen terhadap kumpulan berkas-berkas timesheet tersebut, dan membuat laporan seutuhnya; (9) laporan berupa total waktu kerja dan pengeluaran berdasarkan proyek; (10) laporan berupa total waktu kerja dan pengeluaran berdasarkan karyawan atau 
Engineer; (11) setelah itu laporan yang dibuat oleh SDM diberikan kepada Project Management guna memantau perkembangan proyek.

Sistem pencatatan revisi kerja proyek (Gambar 5) adalah: (1) setiap Designer akan membuat rancangan berupa hardcopy rancangan bangunan. Jika telah diselesaikan, maka akan dikerjakan oleh Drafter; (2) setiap Drafter akan mengerjakan file hardcopy yang telah diberikan oleh Designer berupa $e$-file dan kemudian diberikan kepada Engineer; (3) engineer melakukan finishing rancangan $e$-file; (4) jika hasil akhir dari Engineer telah ditolak oleh client, status berupa IFR (issue for review) dan hasil berikutnya berupa revisi; (5) jika hasil diterima, status file berupa IFA (issue for approval); (6) jika hasil akhir telah diperoleh dan semua berkas atau file telah di setujui oleh client, status file atau berkas berupa IFC (issue for construction) yang menunjukan bahwa file siap diimplementasikan atau dikonstruksikan ke dalam bentuk fisik yang nyata.

Sistem pengajuan cuti adalah (Gambar 6): (1) setiap karyawan membuat surat permohonan ijin cuti; (2) surat izin diberikan kepada SDM, jika disetujui, berkas akan diproses oleh SDM. Jika tidak, karyawan tidak dapat melakukan ijin cuti; (3) SDM membuat surat sebagai bukti cuti dan membuat laporan mengenai data karyawan yang cuti.

Proses pengajuan lembur (Gambar 7) adalah: (1) setiap anggota Engineering proyek diwajibkan meminta ijin untuk kerja lembur kepada Lead; (2) jika Lead mengijinkan, anggota Engineering dapat melakukan kerja lembur dan boleh mengisi laporan waktu kerja untuk data overtime. Jika tidak, anggota Engineering tidak dapat bekerja lembur dan mengisi laporan waktu kerja untuk data overtime.

\section{Permasalahan yang Dihadapi}

Setelah dilakukan analisis terhadap sistem yang telah berjalan pada PT Rekayasa Engineering, diperoleh permasalahan sebagai berikut: (1) pencatatan seluruh data masih dilakukan secara manual sehingga memungkinkan kesalahan dalam pencatatan; (2) pencatatan laporan waktu kerja dilakukan pada periode tertentu sehingga memungkinkan adanya kesalahan berupa ingatan; (3) data yang tidak seragam dan terdapat pengulangan data atau penamaan data yang sama sehingga sulit dalam pengorganisasian; (4) penumpukan berkas transaksi dan laporan yang menyebabkan masalah dalam pencarian berkas.

\section{Sistem yang Diusulkan}

Dari permasalahan yang diperoleh, dapat diajukan beberapa usulan untuk memecahkan masalah tersebut. Usulan tersebut adalah sebagai berikut:

Pertama, merancang dan membuat aplikasi pencatatan waktu kerja atau timesheet harian untuk perusahaan PT Rekayasa Engineering sesuai dengan kebutuhan yang harus terpenuhi. Kebutuhan yang dimaksud sebagai berikut: (1) kebutuhan Project Management \& SCPC, yaitu: pencatatan terhadap total waktu, pencatatan terhadap total pengeluaran biaya, peringatan jika waktu dan pengeluaran yang diperkirakan telah melewati batas yang telah ditentukan, pencatatan terhadap proyek dan status proyek, pecatatan terhadap setiap file proyek, dan hasil akhir laporan berupa excel dari SDM; (2) kebutuhan marketing: pencatatan setiap proposal yang baru maupun yang lama, memperoleh informasi client dan owner berikut bidang usahanya, memperoleh informasi contact person; (3) kebutuhan SDM, yaitu: pencatatan terhadap total waktu, pencatatan terhadap total pengeluaran biaya, hasil akhir laporan berupa excel yang akan diberikan kepada Project Management, laporan berupa semua catatan timesheet yang dapat disortir berdasarkan proyek dan berdasarkan karyawan, dan pencatatan terhadap pengajuan lembur dan pembentukan laporan pertahunan; (4) kebutuhan lead atau pimpinan bagian engineering proyek, yaitu: pencatatan waktu kerja dari bawahannya, pembagian terhadap files kerja 
terhadap bawahannya, dapat menerima dan menolak laporan waktu atau timesheet dari bawahannya, pencatatan terhadap proyek dan status proyek, pencatatan terhadap setiap files proyek, dan pemberian dan pengetahuan mengenai pengajuan lembur dari bawahannya; (5) kebutuhan karyawan atau atau bagian Engineering proyek, yaitu: dapat mengisi timesheet dengan mudah, memperoleh data file yang akan dikerjakan berikut dengan total waktunya, dapat mengisi timesheet sesuai dengan ketentuan yang diberlakukan di PT Rekayasa Engineering, memperoleh informasi mengenai waktu kerja yang telah dilakukan olehnya, mengajukan cuti dan melihat status cuti secara langsung, dan mengajukan lembur dan melihat status lembur secara langsung.

Usulan kedua adalah merancang dan membuat aplikasi yang dapat mengurangi beban dan memudahkan karyawan untuk mengisi dan menyusun laporan waktu kerja mereka.

Usulan ketiga adalah merancang dan membuat aplikasi yang dapat menghasilkan laporan yang tertata dengan baik dan mudah dipahami, guna sebagai bantuan dalam pemantauan kerja dan pengambilan keputusan.

\section{Perancangan Aplikasi}

Perancangan aplikasi dimulai dari pemodelan sistem, dimana beberapa diagram pendukung seperti diagram context digunakan untuk membatasi ruang lingkup aplikasi yang dikembangkan pada penelitian ini. Diagram context sistem dapat dilihat pada Gambar 8. Diagram berikutnya menggambarkan pergerakan data dari aplikasi yang akan dikembangkan. Model yang telah dibuat digambarkan pada Gambar 9.

\section{Perancangan Basis Data}

Hasil dari rancangan basis data akan digunakan untuk mendukung sistem informasi yang akan dikembangkan pada aplikasi ini. Pada database yang dirancang, setiap tabel (entity) yang ada akan dihubungkan dengan menggunakan relationship (Silberschatz, 2002, p8). Entity Relationship Diagram (ERD) yang telah dihasilkan digambarkan pada Gambar 10.

\section{Implementasi Program}

Berikut adalah tampilan-tampilan layar dari aplikasi yang telah dibuat (Gambar 11 15). Jika karyawan berhasil login, halaman yang akan muncul adalah halaman home. Halaman ini akan menampilkan sedikit tentang PT. Rekayasa Industri serta tanggal dari web server. Halaman Karyawan merupakan halaman master yang menampilkan data dari tabel Karyawan, halaman ini bisa digunakan untuk insert, update maupun delete data Karyawan. Halaman ini juga bisa menampilkan detail data dari seorang karyawan. Halaman Proposal merupakan halaman master yang menampilkan data dari table Proposal, halaman ini bisa digunakan untuk insert, update maupun delete data Proposal yang telah dibuat. Halaman ini juga bisa digunakan oleh marketing untuk me-reject atau meng-approve proposal yang telah dibuat. Halaman Pengerjaan File Proyek ini akan menampilkan file-file yang harus dikerjakan oleh karyawan yang telah diberikan hak akses oleh lead proyek-nya untuk mengerjakan file tersebut. Jika hak akses yang diberikan berupa view, otomatis karyawan tersebut tidak dapat melakukan upload file. Halaman ini akan mencatat waktu kerja dari karyawan yang mengerjakan file tersebut. Jam mulai dicatat ketika tombol start di klik dan dalam textboxt akan berisi jam dari server, dan jam akhir akan di catat ketika karyawan meng klik tombol done yang menandakan selesainya dibuat. lain-lain.

Halaman Report Karyawan ini dapat dicetak dan diekstrak ke dalam file word, excel, pdf, dan 


\section{PENUTUP}

Setelah dilakukannya proses analisis dan perancangan aplikasi basis data pada PT Rekayasa Engineering, ditariklah simpulan sebagai berikut: (1) Dengan adanya sistem aplikasi basis data, proses pencatatan waktu kerja, proyek, proposal, lembur, dan cuti menjadi telah terkomputerisasi sehingga pengguna dapat melakukan pencarian data dengan lebih cepat dan tepat dari sebelumnya; (2) Dengan adanya sistem aplikasi basis data, proses pembuatan laporan menjadi lebih cepat dan tepat sesuai dengan seleksi dan persetujuan beberapa pengguna sehingga dapat membantu dalam pengambilan keputusan; (3) Dengan adanya sistem aplikasi basis data, ketepatan data dapat lebih dipertanggungjawabkan dengan pencegah kesalahan di dalam sistem, sehingga dapat mengurangi kesalahan yang dilakukan oleh manusia; (4) Dengan adanya sistem aplikasi basis data, keamanan data perusahaan lebih dapat terjamin dibandingkan dengan penggunaan berkas.

\section{DAFTAR PUSTAKA}

Atzeni, P. (2003). Database System: Concepts, Languages, \& Architectures. New York: McGraw Hill.

Connoly, T. dan Begg, C. (2002). Database System: A Practical Approach to Design, Implementation, and Management (3rd ed.). New York: Addison-Wesley.

Hoffer, J. A., Prescott, M. B., Topi, H. (2009). Modern Database Management (9th ed.). New Jersey: Pearson Education.

O'brien, J. A. (2003). Introduction to Information System : Essentials fot the e-Business Enterprise (11th ed.). New York: McGraw Hill.

Silberschatz, Abraham, Korth, Henry, F. dan Sudarshan, S. (2002). Database System Concepts (4th ed.). New York: McGraw Hill. 
APPENDIX

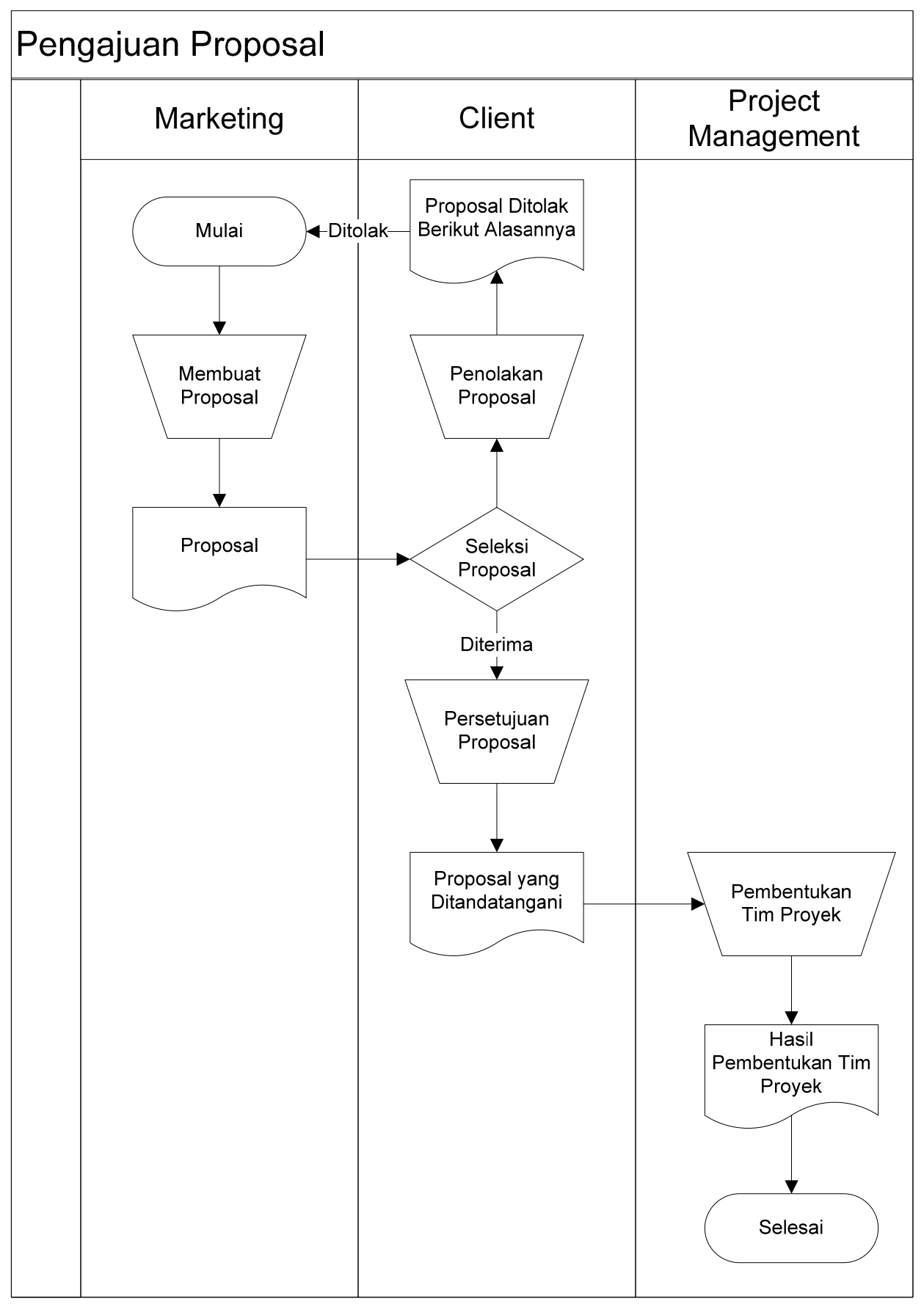

Gambar 2 Proses pengajuan proposal 


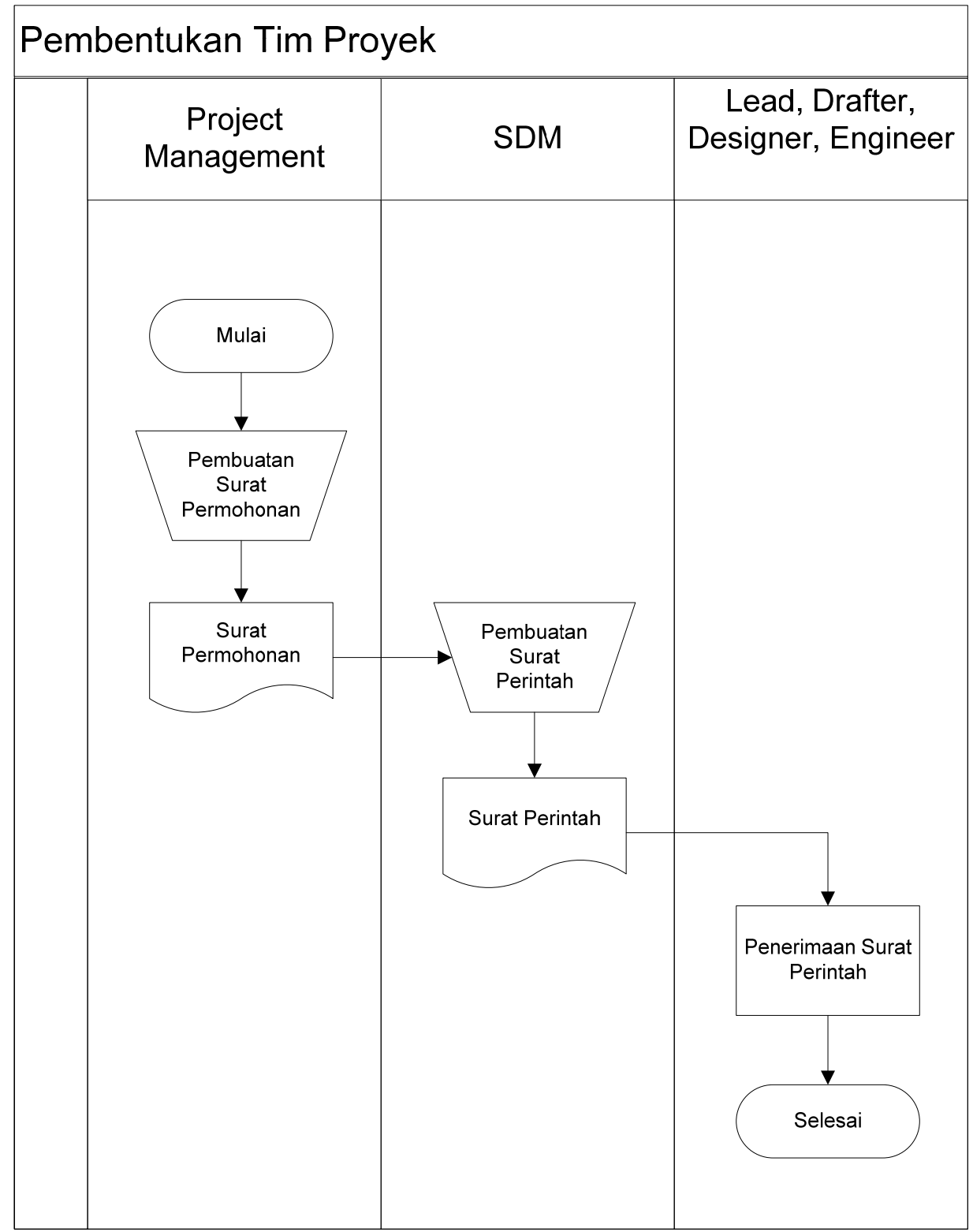

Gambar 3 Proses pembentukan tim proyek 


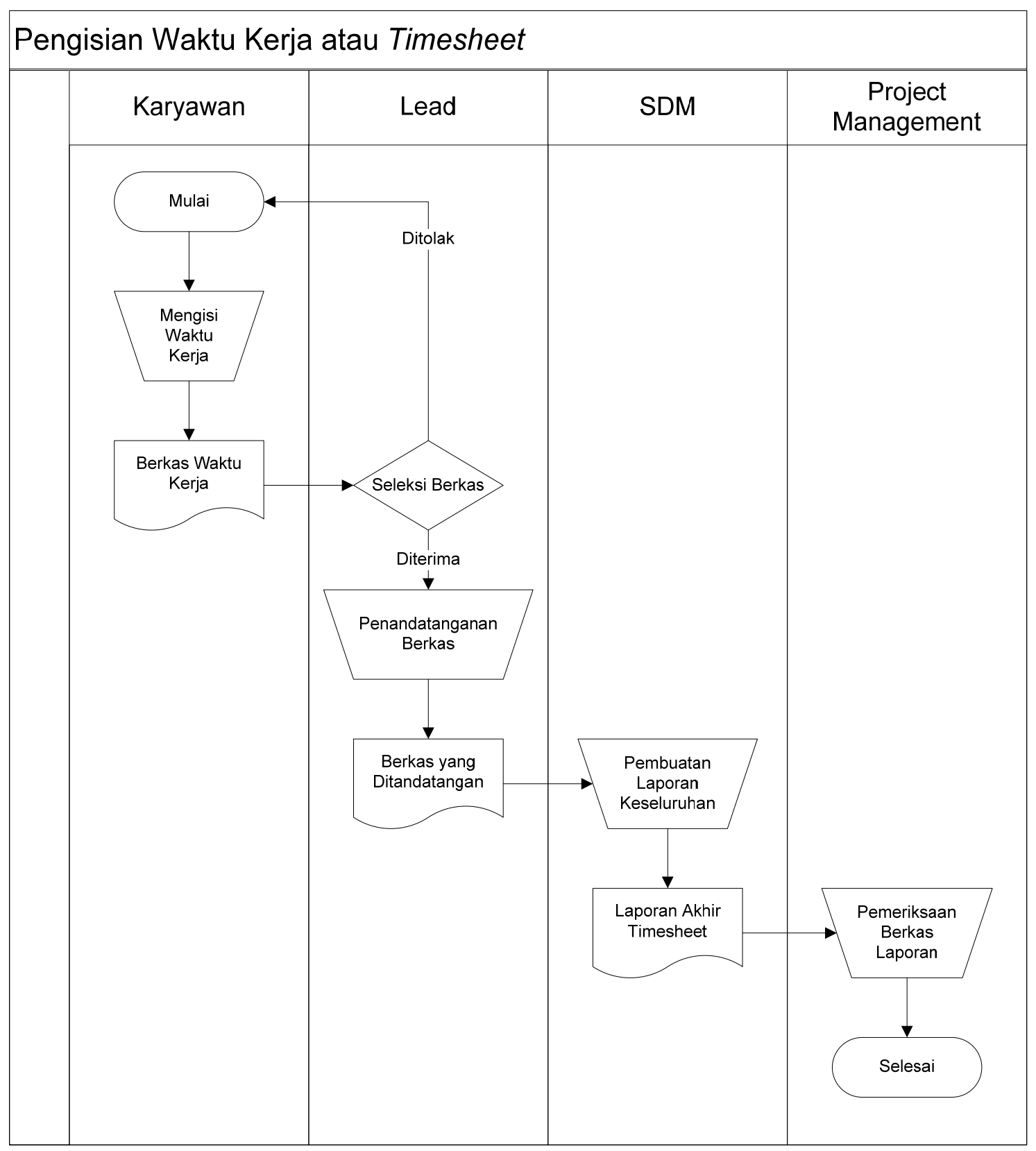

Gambar 4 Proses pengisian waktu kerja atau timesheet 


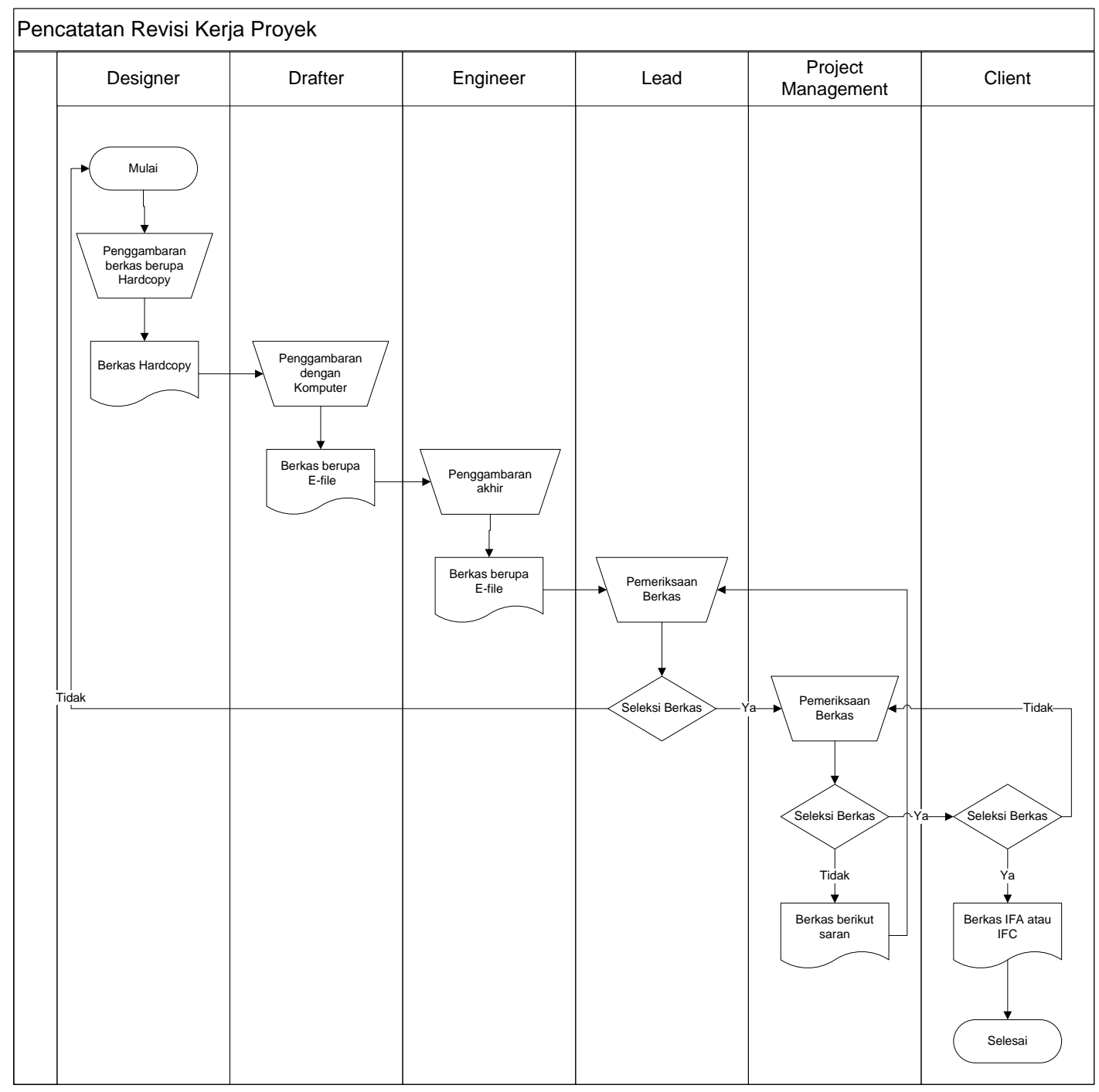

Gambar 5 Proses pencatatan revisi kerja proyek 


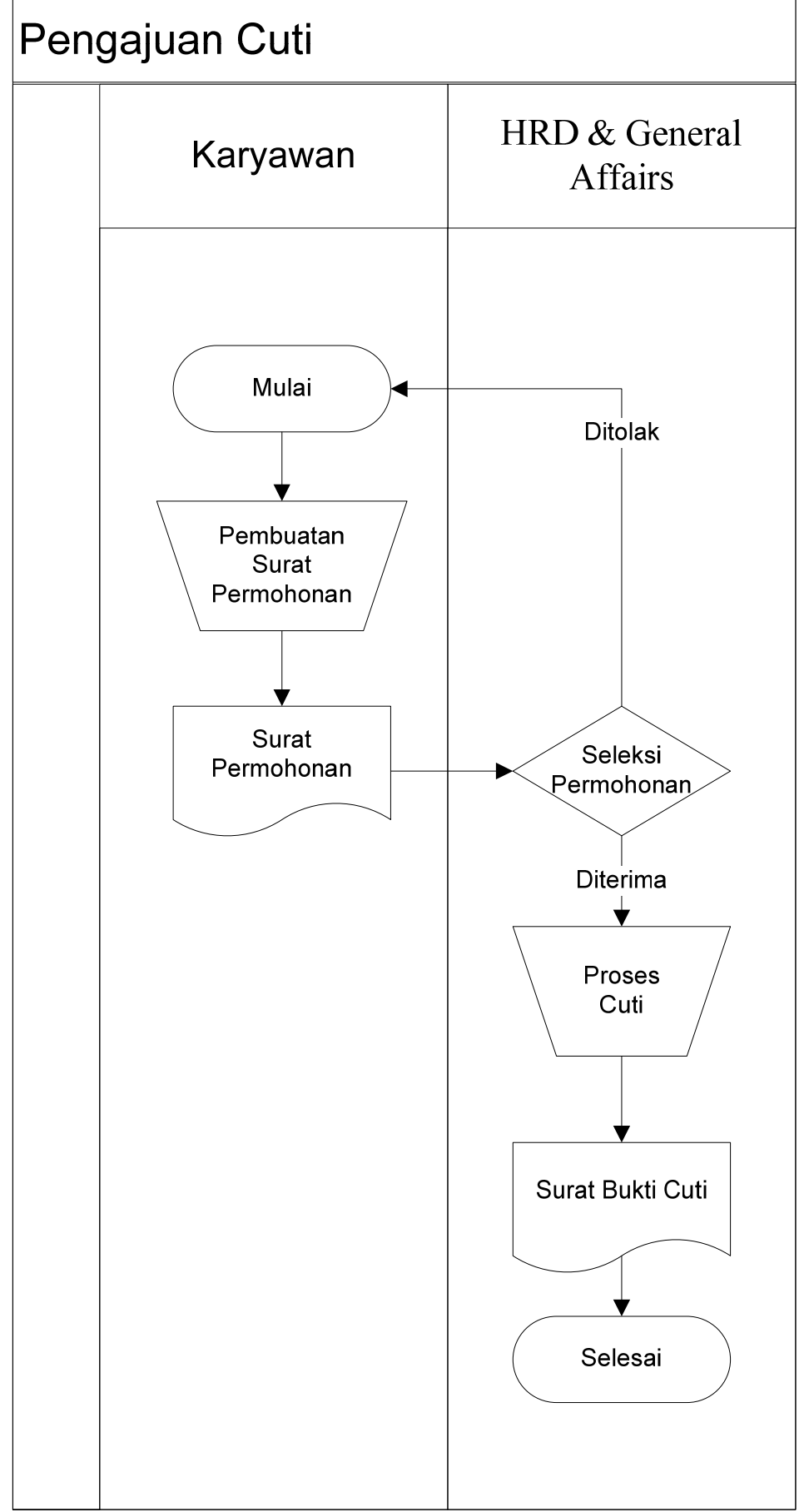

Gambar 6 Proses pengajuan cuti 


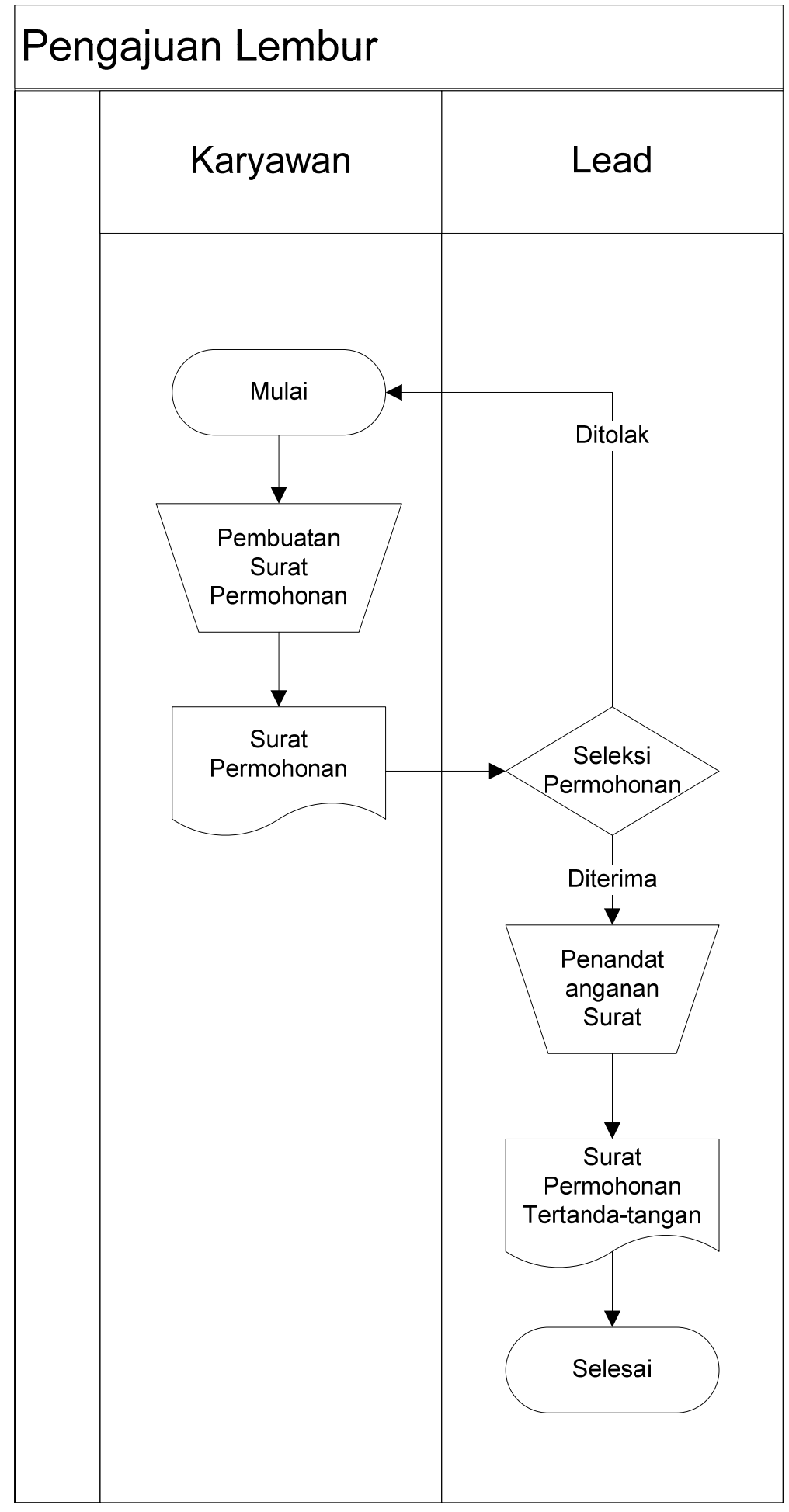

Gambar 7 Proses pengajuan lembur 


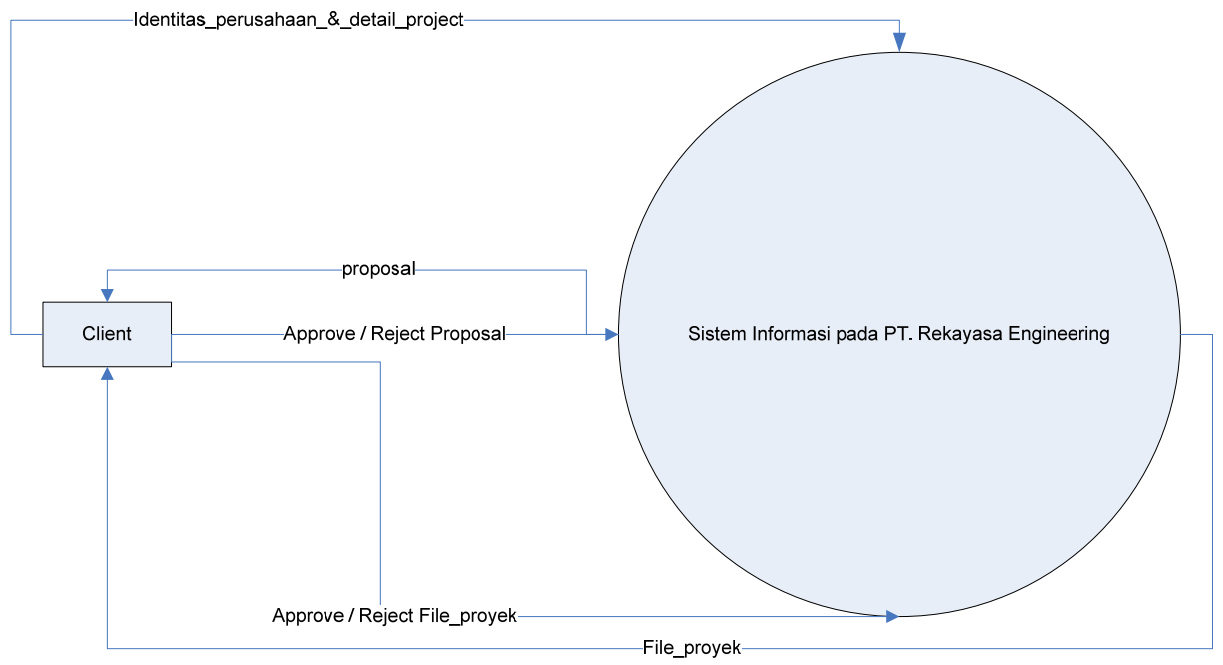

Gambar 8 Context diagram system

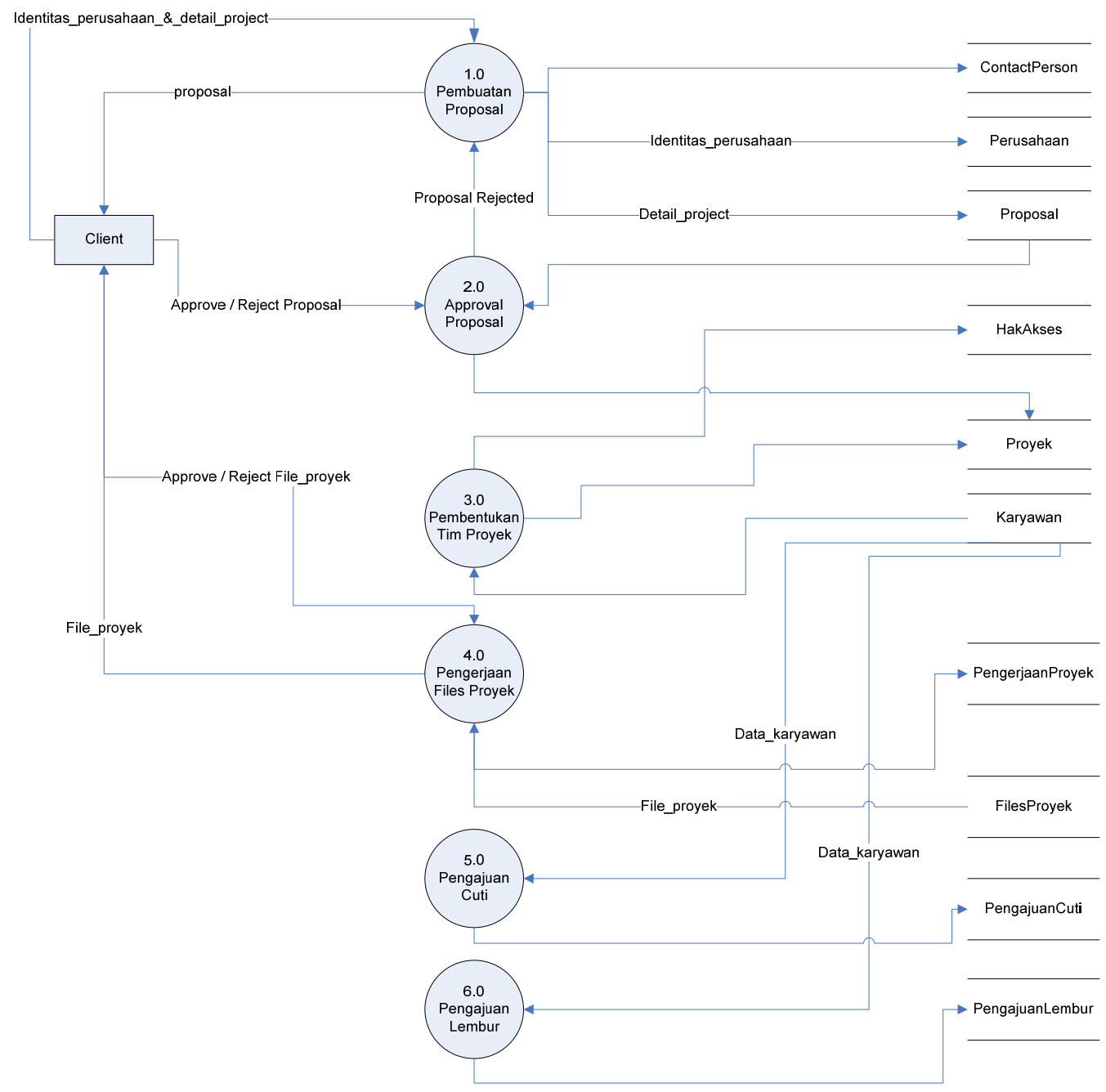

Gambar 9 Diagram nol 


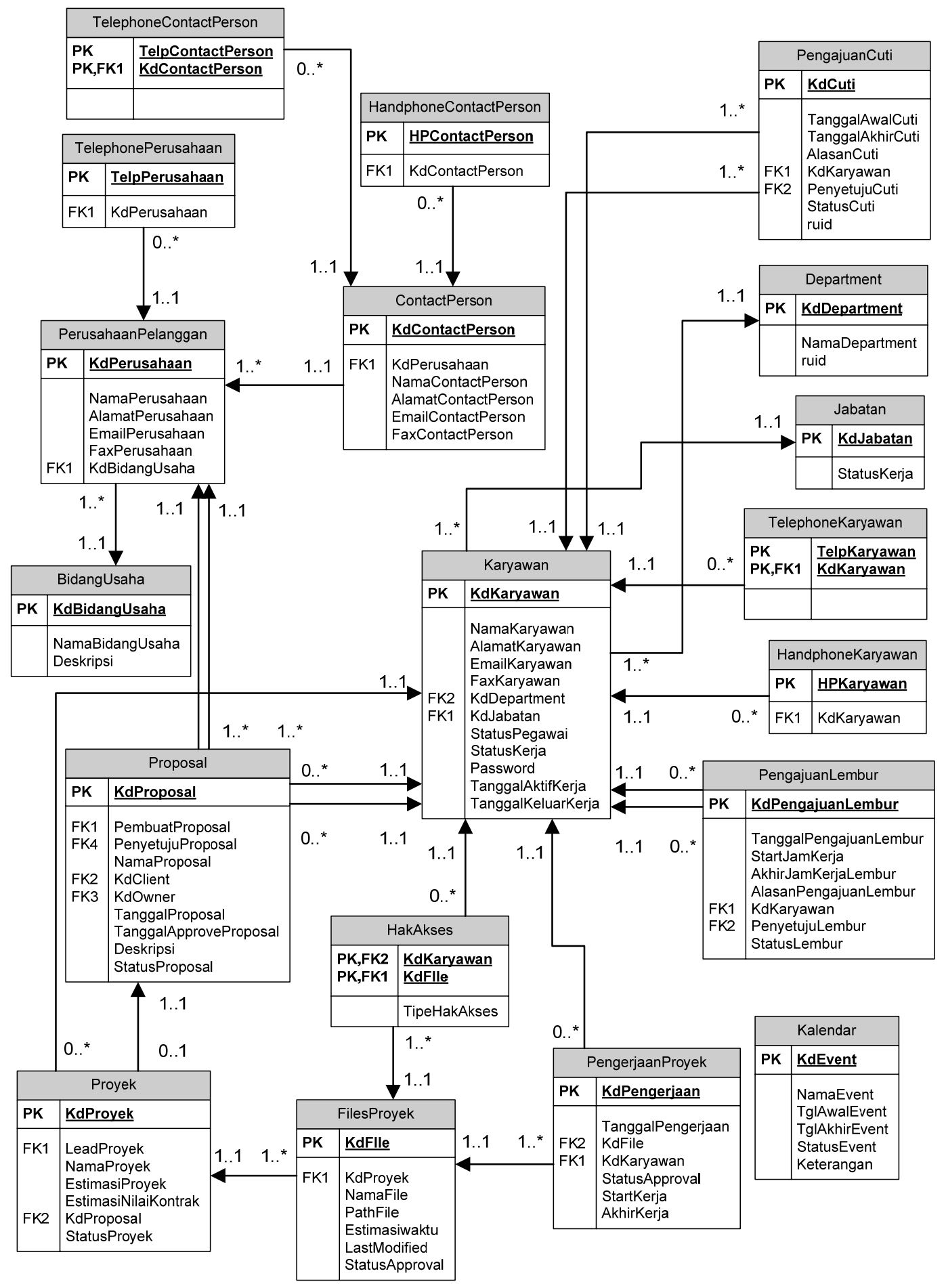

Gambar 10 Entity relationship diagram 


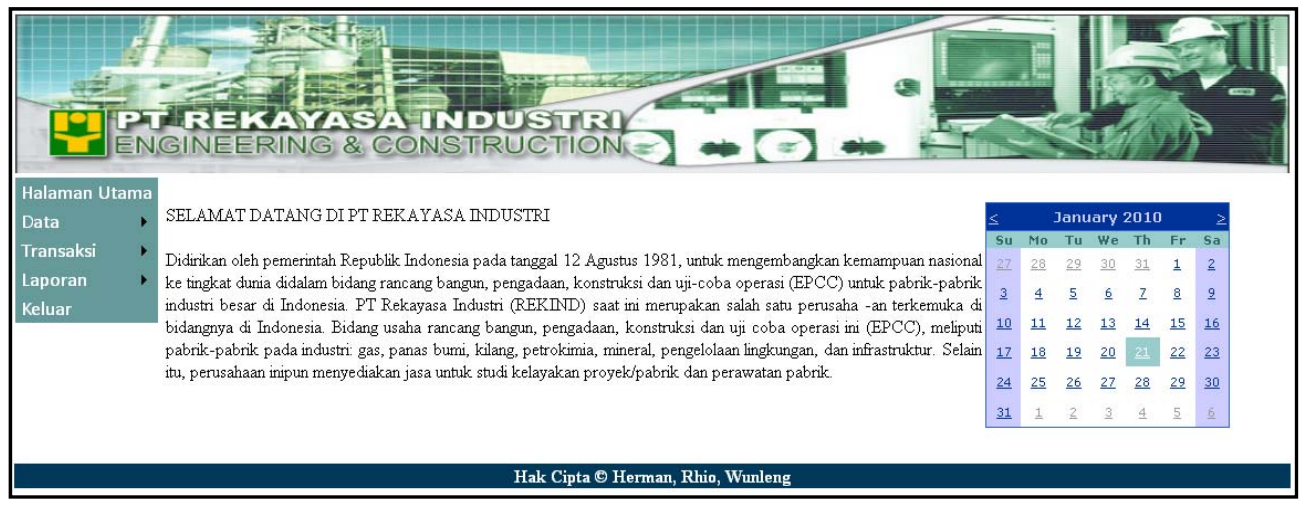

Gambar 11 Tampilan Home

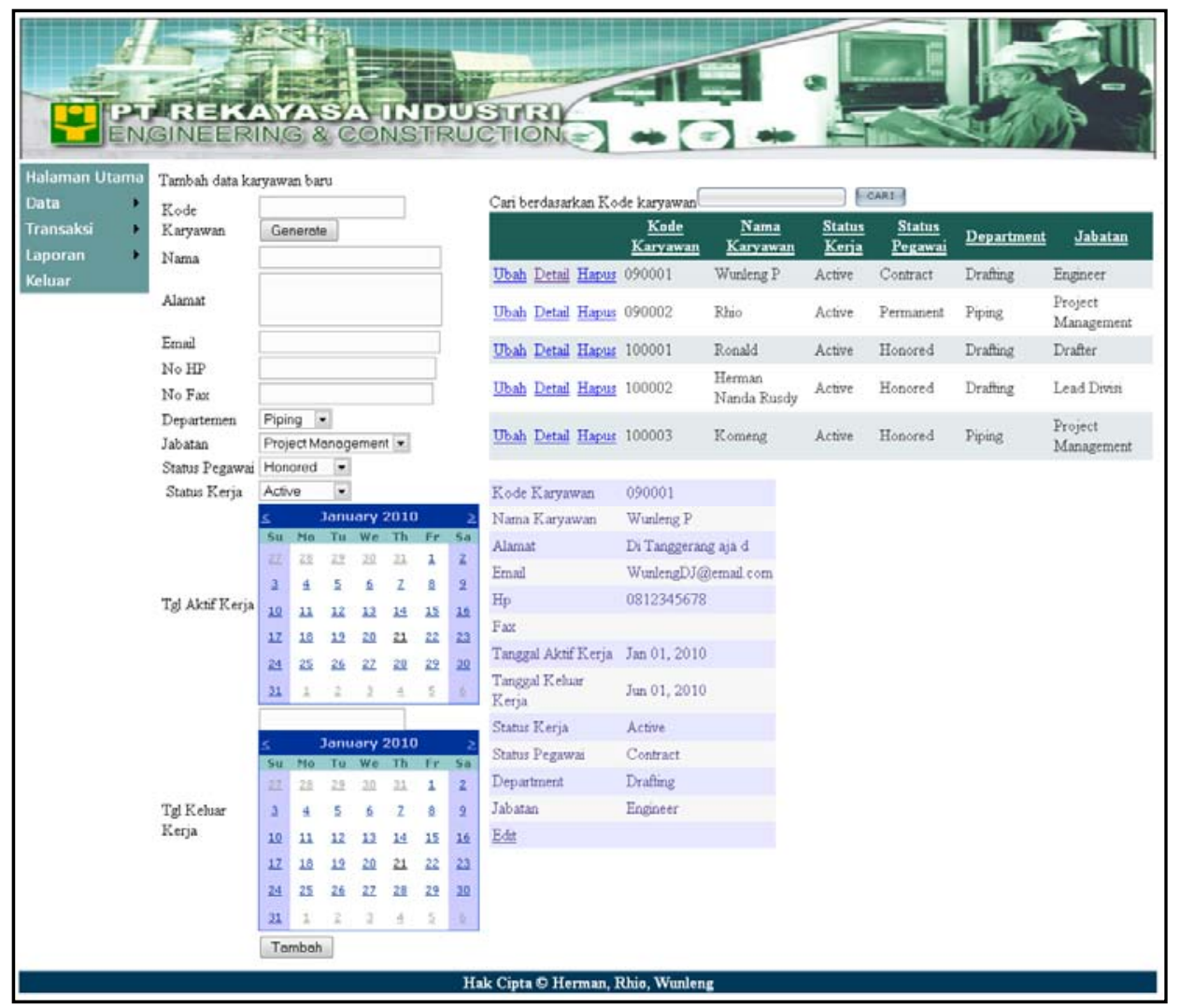

Gambar 12 Tampilan karyawan 


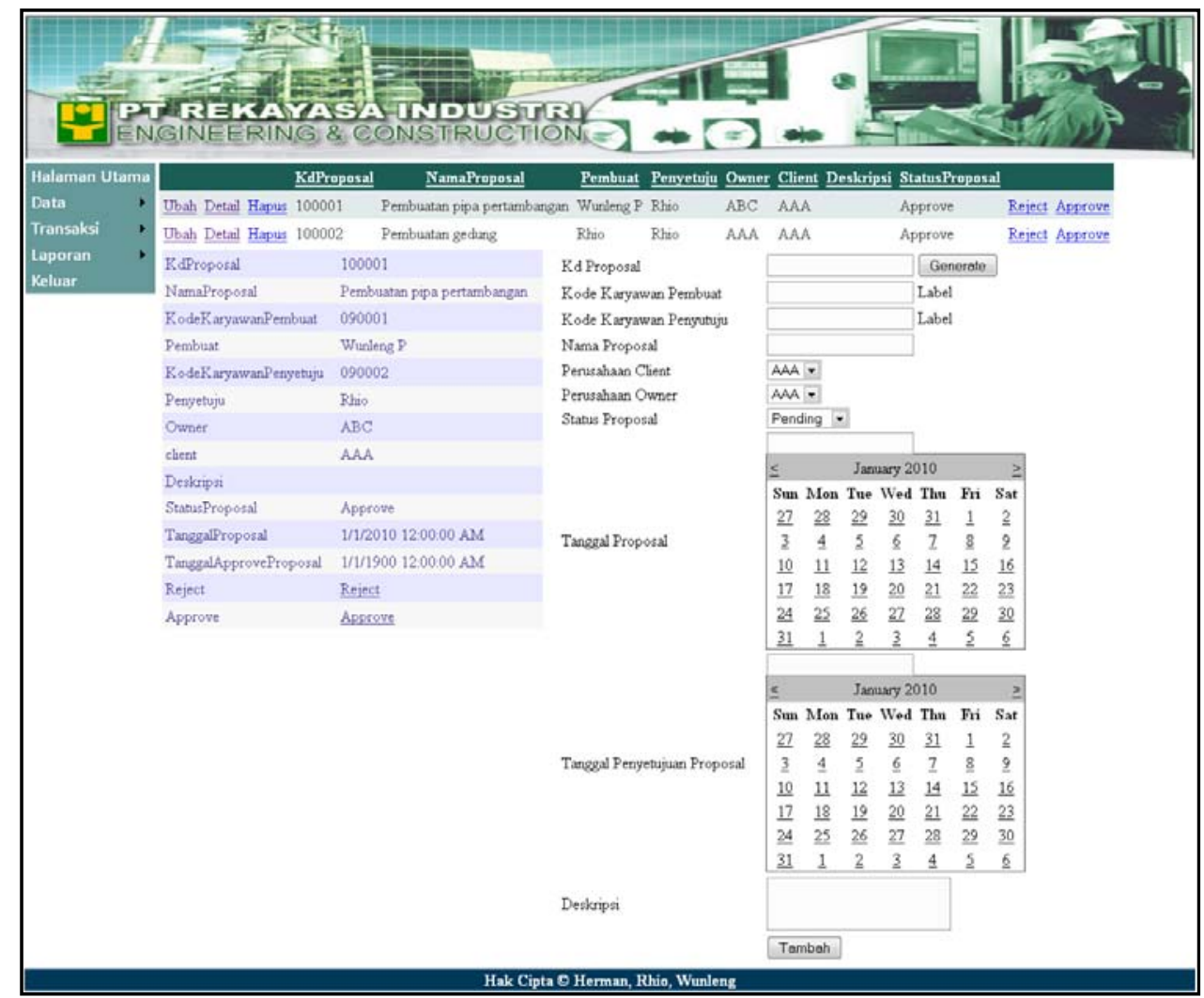

Gambar 13 Tampilan proposal

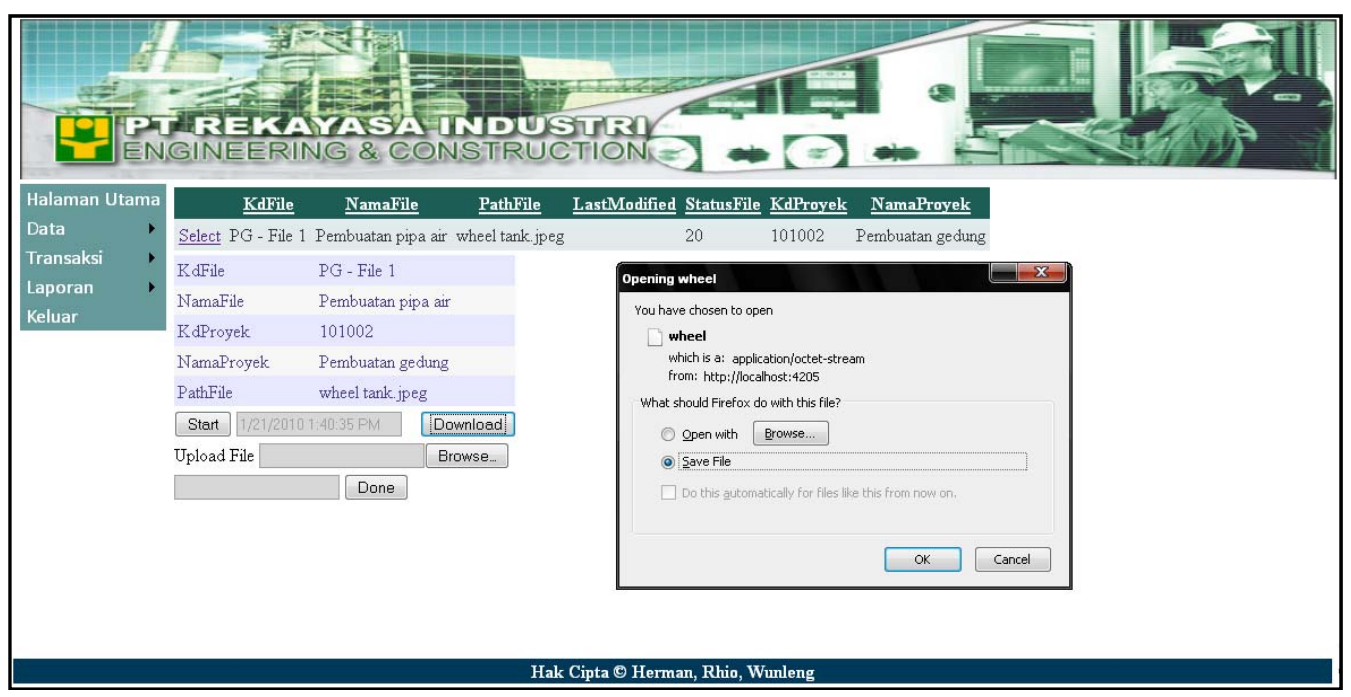

Gambar 14 Tampilan pengerjaan file 


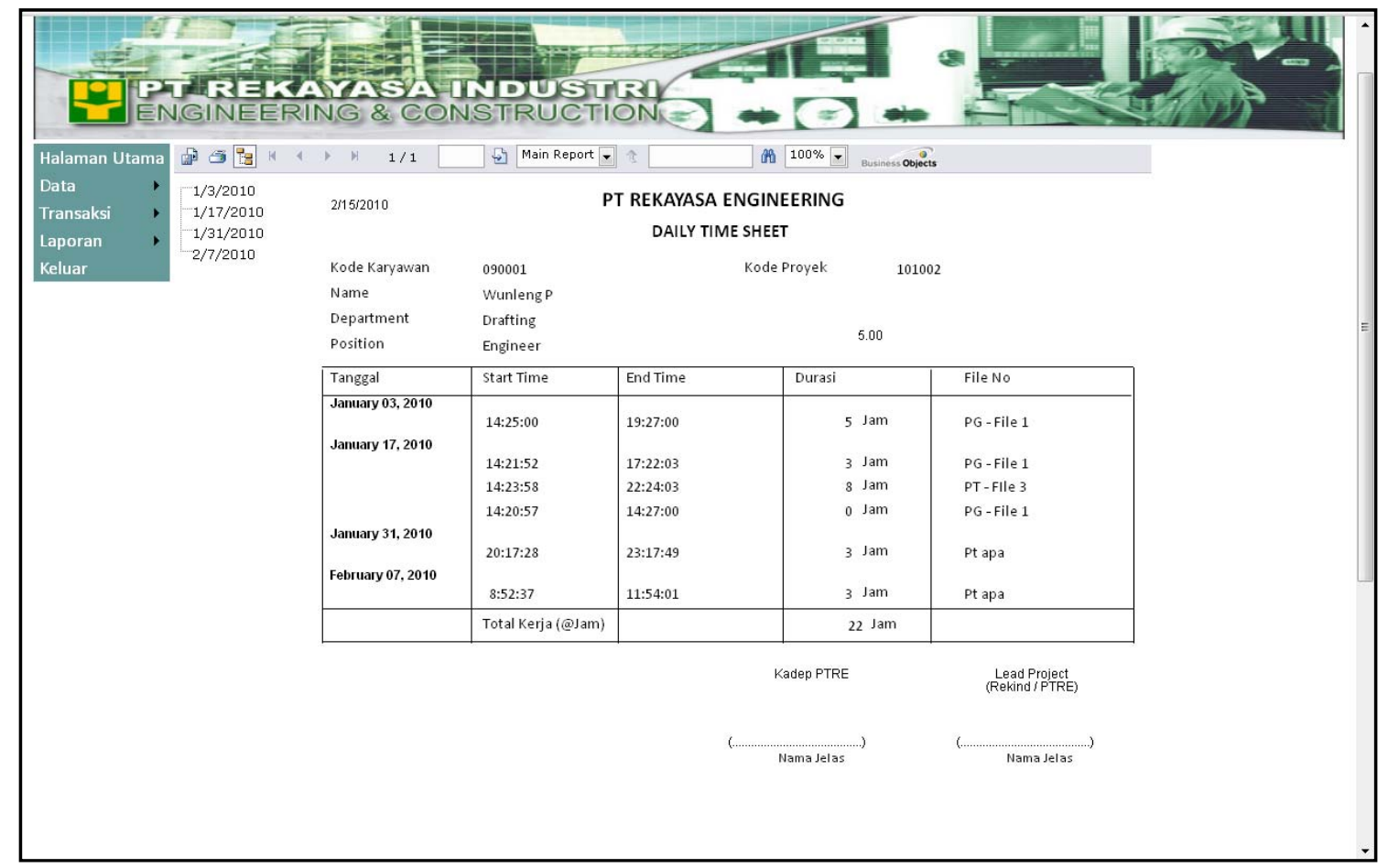

Gambar 15 Tampilan report karyawan 